\title{
LEGAL PERSPECTIVES ON SOCIO-ECONOMIC STATUS OF WOMEN IN AZAD JAMMU AND KASHMIR
}

\author{
Sardar M.A. Waqar Khan Arif \\ Department of Law, University of Kotli Azad Jammu and Kashmir \\ PhD Candidate at International Islamic University Islamabad-cum-Rijks Universiteit Groningen, The \\ Netherlands \\ E-mail: sardarwaqarkhan@gmail.com
}

\begin{abstract}
This article focuses on legal perspectives of women's social and economic status in Azad Jammu and Kashmir (AJK). The bulk of international human rights instruments provide that human rights are available to 'everyone' as grounded in Universal Declaration of human rights (UDHR), (1948) and other human rights instruments. In relation to women, economic, social and cultural (ESC) rights are specifically grounded in UDHR, Women's Convention and the International Covenant of Economic, social and cultural rights (ICESCR), (1966). In this context, this paper analyses relevant provisions of women's rights in order to highlight obligations of AJK pertaining to protection of ESC rights. It discusses the ESC status of women with linkage to Millennium development goals (MDGs). It aims to discuss that what are socio-economic conditions of women in AJK? Is there any pattern of vulnerability in this respect? In general, ESC rights are considered as mere aspirations and goals therefore the Maastricht guidelines are also formulated. The argument developed throughout article is that though AJK is not a State but is state-like entity and has its human rights obligations, in particular, ESC obligations for promotion and protection of women. The women in AJK are vulnerable and may be empowered by promotion of ESC rights.
\end{abstract}

Keywords: economic, social and cultural rights; women in Azad Jammu and Kashmir; human rights

\begin{abstract}
Abstrak
Artikel ini berfokus pada perspektif hukum status sosial dan ekonomi wanita di Azad Jammu dan Kashmir (AJK). Sebagian besar instrumen hak asasi manusia internasional menetapkan bahwa hak asasi manusia tersedia bagi 'setiap orang' yang didasarkan pada Deklarasi Universal Hak Asasi Manusia (UDHR) Tahun 1948 dan instrumen hak asasi manusia lainnya. Kaitannya dengan hak-hak perempuan, ekonomi, sosial dan budaya (ESC) secara khusus didasarkan pada UDHR, Konvensi Perempuan dan Kovenan Internasional Hak-hak ekonomi, sosial dan budaya (ICESCR) Tahun 1966. Dalam konteks ini, artikel ini menganalisis ketentuan-ketentuan perempuan yang relevan untuk menyoroti kewajiban AJK terkait dengan perlindungan hak-hak ESC. Artikel ini membahas status hak ESC perempuan keterkaitanya dengan Millennium development goals (MDGs). Artikel ini bertujuan untuk membahas apa sajakah kondisi sosio-ekonomi perempuan di AJK? Apakah ada pola kerentanan dalam hal ini? Secara umum, hak-hak ESC dianggap hanya sebagai aspirasi dan tujuan, oleh karena itu, panduan Maastricht juga dirumuskan. Argumen yang dikembangkan dalam artikel ini adalah bahwa meskipun AJK bukan Negara tetapi merupakan entitas mirip negara dan memiliki kewajiban hak asasi manusia, khususnya, kewajiban ESC untuk promosi dan perlindungan perempuan. Perempuan di AJK rentan dan dapat diberdayakan dengan promosi hak-hak ESC.
\end{abstract}

Kata kunci: hak ekonomi, sosial dan budaya; perempuan di Azad Jammu dan Kashmir, hak asasi manusia

Introduction

Human rights are available to 'everyone' without any distinction or discrimination. The ESC rights are also human rights and states have obligations to promote, protect and fulfil these rights. In AJK, the economic and social patterns of women are significant for consideration because of their vulnerability. The socio-economic conditions of women in AJK are important for consideration because they face discrimination 
and distinction in relation to protection of their ESC rights. In particular, women living in mountainous and far-flung areas suffer in respect of availability and protection of basic human rights. For example, women do not have direct access to clean and healthy environment. Similarly, fewer opportunities are available for protection of their rights, such as, education, health and employment. It is need of the hour to formulate policies and ensure effective implementation in respect of protection of women's ESC rights. Also it is obligation on AJK to promote and protect ESC rights of women at all levels without discrimination and distinction. In particular, progressive realization of women's ESC rights in AJK is a big challenge. In this context, this paper addresses ESC conditions of women in AJK in order to apprise reader about socio-economic status of women. Based on socioeconomic conditions an attempt is made to highlight AJK's human rights obligations. The structure of the paper is as follows. After an introduction, Section A analyses women's ESC rights with linkage to MDG's and elaborates situation of poverty in AJK in order to create context for further discussion. Section $B$ analyses socio-economic conditions of women in AJK in order to highlight human rights obligations of AJK. It also discusses vulnerability of women. Finally, a brief conclusion of discussion will be drawn.

\section{Research Method}

This study is a qualitative analysis of legal instruments pertaining to women's ESC rights. This study analyses relevant legislation in order to clarify the situation on the subject. In other words, it is an empirical research. The primary sources of data are books, research articles, reports and international legal instruments. The secondary sources include internet and technological sources.

\section{Discussion}

\section{Women's ESC rights in AJK and MDG's}

AJK Interim Constitution Act (ICA), (1974) guarantees certain fundamental human rights available to all individuals including women.
The covenant on ESC rights recognizes women's rights and it is obligation on AJK to protect ESC rights of women. Article 4 (1) of ICA states that No person shall be deprived of liberty save in accordance with law.

Article 8 of the ICESCR recognizes right of everyone to form trade unions or associations for the promotion and protection of his economic and social interest. Moreover, article 4 of the ICESCR recognises the right of everyone to the enjoyment of just and favourable conditions of work. Under article 4 (9) every individual will try his best to make friendly relations with $\mathrm{Pa}$ kistan. Moreover it is obligation on everyone to respect public order, decency or morality. Discrimination is prohibited under article 4 (17) of the AJK constitution. It states that no State individual who is qualified for appointment in the service of AJK shall be discriminated against in respect of any such appointment on the ground only of race, religion, caste or sex. In the interest of the said service, specified posts or services may be reserved for members of either sex.

MDG's contain clear quantitative standards to which all Governments have made a political commitment. There was strong emphasis on aligning them closely with the relevant economic and social rights obligations, and on ensuring that the targets and indicators address the human rights of women and excluded groups. It noted that countries could adopt additional human rights-related goals. ${ }^{1}$ Each of the MDGs aims to fulfil a particular civil, economic, or social right.

For instance, the right to life (goal 4 reduce child mortality), the right to development and right to an adequate standard of living and food (goal 1 eradication of extreme poverty), the right to education (goal 2 achieving universal primary education), the right to non-discrimination (goal 3 promoting gender equality and empowering women), the right to health (goal 5 improving maternal health). Consequently, analysis of the MDG goal 3 promoting gender equality and empowering women must include a hu-

\footnotetext{
Jan Vandemoortele, “MDGs: Misunderstood Targets?” International Poverty Centre, No 28, January, 2007.
} 
man rights perspective. Progress is lagging for achieving MDG 3. AJK needs more progress towards the achievement of promoting gender equality and empowering women (MDG 3). AJK Parliament should observe quantitative standards, address patterns of discrimination, and strengthened strategies for empowerment of women in enjoyment of their ESC rights keeping in view the MDGs targets and indicators.

Share of women in wage employment in non-agricultural sector is $4.45 \%$. Gender parity index in secondary education is $0.89 \%$. Gender parity index in primary education is $1.01 \%$. Youth literacy GPI is $0.53 \%$. Overall all these indicators of this goal are off-track; AJK is unlikely to meet MDG 3. Unfortunately, since the 2005 earthquake which struck AJK in 2005, significant amount of resources continue to be used for recovery and rehabilitation thereby negatively impacting the allocation of funds for development interventions. ${ }^{2}$ Indicators show that level of participation is low. AJK still falls of the MDG targets set for 2015. In this context, AJK government has to make laws and policies for achieving gender equality and women empowerment.

Women empowerment and participation, which are key human rights principles, has become a standard feature of development discourse. The third key recommendation of the Millennium Project focused on the need for broad-based participation in implementing the Goals. Private sector firms and organizations should contribute actively to policy design, transparency initiatives and, where appropriate, public-private partnerships. ${ }^{3}$

WHO is committed to the attainment of the United Nations MDGs. Health is a means to reduce poverty and attain sustainable economic development. ${ }^{4}$ MDGs have relationship with basic human rights and provisions of AJK consti-

2 Ministry of Planning Development and Reform, 2013, Pakistan Millennium Development Goals Report, Islamabad: Ministry of Planning Development and Reform.

3 Millennium Project, 2005, Investing in Development: A Practical Plan to Achieve the Millennium Development Goals, Overview, London: Earth scan.

4 Statement by World Health Organization, UN Commission on Human Rights, Agenda item 10, Economic, Social and Cultural rights, Geneva, April 2003. tution are also consistent. Keeping in view above recommendation ESC rights of women in AJK needs to be protected and promoted. For example, In AJK'S Interim constitution certain fundamental rights are recognized and protectted. Article 15 states that: All persons are equal before law and are entitled to equal protection of law. This provision includes women as well. Article 17 safeguards against discrimination in service. These provisions also apply to women in theory however, in terms of implementation in AJK, these rights faces challenges, for example, women are neglected in getting education, food, health care facilities, consent for choice of a life partner and other essentials of life. ${ }^{5}$

Achieving gender equality in education requires equality of access and opportunity to education, as well as equality of treatment once in school for girls and boys alike. Gender parity in education refers to the equal enrolment of girls and boys in school. To sustain and build on the gains made in improving gender parity in education, the wider issues of equality of opportunity and equality of treatment have to be addressed. ${ }^{6}$

Commitment 7 (d) of the Johannesburg Plan of Implementation was to "Promote women's equal access to and full participation in, on the basis of equality with men, decision-making at all levels, mainstreaming gender perspectives in all policies and strategies, eliminating all forms of violence and discrimination against women and improving the status, health and economic welfare of women and girls

5 Muhammad Hassan, 2005. The Roles of Gender in Azad Kashmir. Urdu Edition. Mirpur: Bukhari Printing Agency Mirpur). See also Falendra K. Sudan, "Livelihood Diversification and Women Empowerment Through SelfHelp Micro Credit Programme: Evidence from Jammu and Kashmir", Indus Journal of Management \& Social Sciences, Vol. 1 No. 1, Fall 2007, pp. 90-106; Showkeen Bilal Ahmad Gul, "Assessment and Understanding of Gujjar and Bakerwal Women's Health in Jammu and Kashmir", Journal of Business Management \& Social Sciences Research, Vol. 3 No. 3, March 2014, pp. 37-43.

6 United Nations Report on Indicators for Promoting and Monitoring the Implementation of Human Rights. Realizing the Future We Want for All: Report to the Secretary-General. UN System Task Team Report on the Post-2015 Development Agenda, June 6, (2008). Available on: www2.ohchr.org/english/bodies/icm-mc/ docs/HRI.MC.2008.3EN.pdf, accessed on 20 December 2017. 
through full and equal access to economic opportunity, land, credit, education and healthcare services". ${ }^{7}$

The UN Task Team report states that: "Discrimination against women and girls impairs progress in all other areas of development. The global development agenda should seek not only to address and monitor the elimination of specific gender gaps, but also to transform the structural factors that underpin the widespread persistence of gender inequalities, genderbased violence, discrimination and unequal development progress between women and men, girls and boys. The empowerment of women and girls and the protection of their rights should be centre-pieces of the post-2015 agenda". ${ }^{8}$

The need of the hour is to promulgate and legislate at domestic level so that women are empowered and they exercise their ESC rights without discrimination and enjoy full participation in exercising their rights. This is the possible solution for improving their empowerment and socio-economic status, as they are vulnerable.

\section{Situation of poverty in AJK}

Poverty is inclusive in AJK with $40 \%$ of the population dwelling in absolute poverty having less than one US dollar per day incomes. ${ }^{9}$ Women living in AJK are facing disadvantages from the time they are born. The birth of a girl is commonly met with dissatisfaction, even irritation and the guilt is usually placed on the mother. As a rule, the girl child receives less food, less access to education and less health care than a male child and as a result girls are more

7 UNDESA, “Chapter 2: Poverty Eradication", Johannesburg Plan of Implementation, (2004) Available on website: www.un.org/esa/sustdev/documents/WSSD POI_PD/English/POIChapter2.htm, accessed on December, 2017.

8 United Nations Report on Indicators for Promoting and Monitoring the Implementation of Human Rights. Realizing the Future We Want for All: Report to the Secretary-General. UN System Task Team Report on the Post2015 Development Agenda, June 6, (2008). Online Available at: www2.ohchr.org/english/bodies/icm-mc/docs/ HRI. MC.2008.3EN.pdf, accessed on: December, 2017.

9 AJK Economic Review. 2011. Azad Kashmir Economic Review. Muzaffarabad: Kashmir Government Press. likely to die of childhood diseases. ${ }^{10}$ Promotion and promotion of ESC rights and women empowerment is understood as to give power to women for having not only the resources and opportunities but also the ability to utilize these resources and opportunities for their personal, economic and social change. ${ }^{11}$

Women's particular vulnerability to social and economic deprivation is deepened further in conflict and post-conflict situations and when economic sanctions are imposed. The CESCR has stated that ESC rights must be taken into account when imposing sanctions, and State Parties to the Covenant should take account of the suffering that such sanctions are likely to inflict on vulnerable groups, such as women. As the UN Security Council has recognized, peace and women's equality are inextricably linked. ${ }^{12}$

AJK is one of the poorest areas, with annual per capita income ranging from USD 180 to 200 , about half the national average. Land degradation, farmland fragmentation and reduced agricultural productivity are jeopardizing the traditional lifestyle and forcing increasing numbers of the poor to migrate in search of off-farm employment. Around $88 \%$ of the population live in rural areas and are dependent on forestry and agriculture for their livelihoods. ${ }^{13}$

In AJK females are also playing their role in the development of economy and to fulfil the needs of their families but this rate of participation is comparatively low because of the religious and cultural restrictions. Out of 49 seats 5 seats are allocated to Women in AJK'S parliament. According to the world development indicators, women in AJK are participating $23 \%$ in the labour force of AJK. Prominently they are providing services in agriculture, edu-

10 Shelly J. Lundberg and Robert A. Pollak, “Non-cooperative Bargaining Models of Marriage", American Economic Review Papers and Proceedings, Vol. 84 No. 2, 1994, pp. 132-137.

11 Charlier Sophie and Lisette, June 2007, Working Group of The Commission on Women Development, The Women Empowerment Approach- a Methodological Guide, Caubers, available on website: http//www.dgcd.be, accessed on November 2017.

12 Security Council Resolution, 1325 Year 2000.

13 International fund for Agricultural Development, "Planned project activities 2002-2003 addendum", Paper/Report, Executive Board-Seventy-Seventh Session, Rome, 10-11 December, 2002. 
cation, health, in professional and business. Labour force participation rate is the proportion of the population, ages 15 and older that is economically active and contributing in household expenditures. The next section is specific to economic and social conditions of women in AJK.

\section{Socio-Economic Conditions Of Women in AJK}

Gender: Women have significantly lower economic opportunities, mobility, access to resources and autonomy in AJK due to cultural and religious customs and other forms of gender discrimination. Health conditions: Children are visibly malnourished, have discoloured hair, have distended stomachs and vacant looks. Women look very old for their years, marry young. People have disabilities or scaring related to diseases, such as small pox. Social conditions: Women are living under social conditions in which it is difficult for them to assert their rights and they are often exploited by wealthier people. A "feudal" elite dominates rural society. Farmers are dependant for their basic needs on a traditional landlord, and do not have property rights over their land. Rural society is male-dominated. Since men control the markets and trading, women are therefore cut off from economic opportunity. Women have little control over how the money is spent and are not aware of how much they really earn. ${ }^{14}$

Women Education is very crucial variable of the study, because it affects the overall socio economic conditions of women, especially in decision making regarding employment, time allocation in domestic activities, maternal health, sanitation and hygiene, and their medical

14 Case Study prepared by Mary McVay, consultant, in conjunction with: Linda Jones and Helen Loftin, Mennonite Economic Development Associates (MEDA) and Economic and Career development Institute (EDCI) funded by the USAID Implementation Grants program (IGP), 2003-2007. See also and comparte with article from Sarita Sood and Arti Bakshi, "Quality of life: Gender differences in aged Kasmiri migrants in Jammu, India", AP Journal Psychological Medicine, Vol. 15 (2) July-Dec 2014, pp. 187-192; V. Bhaskar and B. Gupta, "India's Missing Girls: Biology, Customs and Economic Development", Oxford Review of Economic Policy, 23, 2007, pp. 221-238; R. Chamarbagwala "Economic Liberalisation and Wage Inequality in India", World Development, 34(12), 2006, pp. $1997-2005$ checkups etc. ${ }^{15}$ Women are subjected to discrimination and violence on daily basis. Study implies that women face discrimination and neglect at all levels in our society. They have the sense of being inferior, imposed by the tradetional thoughts of a male chauvinist society; women are suffering tremendously especially in their homes. Lack of education and economic opportunities for women restrict the potential of women to think about their due rights.

Poverty is also big hurdle in the way of Pakistani women becoming progressive and independent. Until and unless the traditional thoughts regarding women as inferior, or as chattel are changed, it might be difficult for women to get any sort of freedom in this environment. Pakistan may not become a prosperous country in the world unless the half of the population consisting of women is given equal opportunities to take part in this process of development. ${ }^{16}$

\section{Women's Vulnerability Seeks Attention}

The patterns of vulnerability mentioned above to the hazards can partially be surmised from the damage of the 2005 Earthquake. Similar patterns of vulnerability are present in relation to most hazards. A brief review of the earthquake studies illustrates the point about

15 Ajaz Ahmed, “Impact of Rooftop Rain Water Harvesting (RRWH) Technology on Women Time Allocation in Hilly and Fragile Areas of Bagh and Battagram Districts", 27th AGM and Conference Papers, 2015, p. 10

16 Muhammad Asif, "Violence against Women in Pakistan: Role of Police and Media", Social Sciences Review of Pakistan, Vol. 1 Issue 1, 2011, p. 13. Read and compare with article from Mary Ellsberg, Loris Heise, Rodolfo Pena, Sonia Agurto, Anna Winkvist, "Researching Domestic Violence against Women: Methodological and Ethical Consideration", Studies in Family Planning, Vol. 32. No. 1 (Mar., 2001), pp. 1-16; Neil M. Malamuth and James V.P. Check, "The Effects of Mass Media Exposure on Acceptance of Violance against Women: A Field Experiment", Journal of Research in Personality 15, 1981, pp. 436-446; Michael P. Johnson, "Patriarchal Terrorism and Common Couple Violence: Two Forms of Violence against Women", Journal of Marriage and the Family, Vol. 57, No. 2 (May, 1995), pp. 283-294; Schuler S.R., Hashemi S.M., Riley A.P. and Akhter S., "Credit Programs, Patriarchy and Men's Violence against Women in Rural Bangladesh", Soc.Sci Medicine, Vol. 43 No. 12, 1996, pp. 1729-1742; Sen P., “Enchancing Women's Choices in Responding to Domestic Violence in Calcutta: A Comparison of Employment and Education", The European Journal of Development Research, Vol. 11 No. 2, December 1999, pp. 65-86. 
the differential vulnerability of the women, children and the elderly. Studies indicate that urban population was particularly vulnerable to the earthquake. ${ }^{17}$ It is argued that domestication of international legal norms for protection of ESC rights and effective implementation is inevitable.

\section{Conclusion}

From the preceding discussion it is concluded that ESC rights of women may be protected in the light of norms of International law by AJK. The constitutional status of AJK is though not clear but at least human rights obligations are incumbent on AJK government. The constitution was designed as temporary arrangement and government was established because future status is yet to be determined.

People living in AJK are poor economically and socially. They have less sources of income. Socio- economic and socio-cultural conditions of women are not good. Poverty index in AJK is high and in this regard; there are challenges on AJK government for example nonavailability of educational institutions, lack of health facilities and less employment opportunities. Women's activities are limited to their homes and have fewer opportunities for working. They can prove better teachers and doctors. It is therefore responsibility of AJK government to protect basic human rights of the peo-

17 Fawad Khan and Daanish Mustafa, Navigating the Contours of the Pakistani Hazardscapes: Disaster Experience versus Policy, Chapter 8, May, 2007, retrieved on: https://thebookee.net/fa/fawad-khan, access on November 2017. See also Ruby Charak, Cherie Armous, Ask Elklit, Disket Angmo Jon D. Elhai \& Hans M. Koot, "Factor structure of PTSD, and relation with gender in trauma survivors form India" European Journal of Psychotraumatology, 5:1, 2014, pp. 1-11; C. Armour, J.D. Elhai, C.M. Layne, M. Shevlin, E. Durakovic-Belko, N. Djapo, "Gender Differences in the factor structure of posttraumatic stress disorder symptoms in war-exposed adolescent”, Journal of Anxiety Disorders, 25, 2011, pp. 604-611; G.J.G. Asmundson, J.A. Stapleton \& S. Taylor, "Are avoidance and numbing distinct PTSD sympotoms clusters?, Journal of Traumatic Stress, 17, 2004, pp. 467-475; P.S. Chandra, V.A. Satyanarayana \& M.P. Carey, "Women reporting intimate partner violence in India: Association with PTSD and depressive symptoms", Archives of Women's Mental Health, 12, 2009, pp. 203209; S.A. Freedman, N. Gluck, R. Tuval-Mashiach, D. Brandes, T. Peri \& A.Y. Shalev, "Gender differences in responses to traumatic event: A prospective study", Journal of Traumatic Stress, 15, 2002, pp. 407-413. ple especially women in AJK so that they may exercise and enjoy their ESC rights equally without any discrimination and distinction.

\section{Suggestion}

It is need of the hour to protect ESC rights of women in AJK by legislation and effective implementation. At least, norms of ICESCR should be domesticated in order to ensure protection of women in social and economic context. The pattern of vulnerability concerning women in AJK needs special attention. AJK may take necessary steps and measures for progressive realization of ESC rights at all levels.

\section{References}

Ahmed, Ajaz. "Impact of Rooftop Rain Water Harvesting (RRWH) Technology on Women Time Allocation in Hilly and Fragile Areas of Bagh and Battagram Districts". 27th AGM and Conference Papers, 2015. Pp. 123;

AJK Economic Review. 2011. Azad Kashmir Economic Review. Muzaffarabad: Kashmir Government Press;

Armour, C., J.D. Elhai, C.M. Layne, M. Shevlin, E. Durakovic-Belko, N. Djapo, "Gender Differences in the factor structure of posttraumatic stress disorder symptoms in war-exposed adolescent". Journal of Anxiety Disorders, 25, 2011, pp.604-611;

Asif, Muhammad. "Violence against Women in Pakistan: Role of Police and Media". Social Sciences Review of Pakistan. Vol. 1 Issue 1. 2011;

Asmundson, G.J.G., J.A. Stapleton \& S. Taylor, "Are avoidance and numbing distinct PTSD sympotoms clusters?". Journal of Traumatic Stress, 17, 2004, pp. 467-475;

Bhaskar, V., and B. Gupta. “India's Missing Girls: Biology, Customs and Economic Development". Oxford Review of Economic Policy, 23, 2007, pp. 221-238;

Chamarbagwala, R. "Economic Liberalisation and Wage Inequality in India". World Development, 34(12), 2006, pp. 1997-2005;

Chandra, P.S., V.A. Satyanarayana \& M.P. Carey. "Women reporting intimate partner violence in India: Association with PTSD and depressive symptoms". Archives of Women's Mental Health, 12, 2009, pp. 203-209; 
Charak, Ruby., Cherie Armous, Ask Elklit, Disket Angmo Jon D. Elhai \& Hans M. Koot. "Factor structure of PTSD, and relation with gender in trauma survivors form India". European Journal of Psychotraumatology, 5:1, 2014, pp. 1-11. 25547, DOI: 10.3402/ ejpt.v5.25547;

Charlier Sophie and Lisette Caubers. June 2007. "Working Group of The Commission on Women Development. The Women Empowerment Approach-a Methodological Guide". available on: http//www.dgcd. be. accessed on November 2017; Hassan, Muhammad. 2005. The Roles of Gender in Azad Kashmir. Urdu Edition. Mirpur: Bukhari Printing Agency Mirpur;

Ellsberg, Mary., Loris Heise, Rodolfo Pena, Sonia Agurto, Anna Winkvist. "Researching Domestic Violence against Women: Methodological and Ethical Consideration". Studies in Family Planning, Vol. 32. No. 1 (Mar., 2001), pp. 1-16;

Freedman, S.A., N. Gluck, R. Tuval-Mashiach, D. Brandes, T. Peri \& A.Y. Shalev. "Gender differences in responses to traumatic event: A prospective study". Journal of Traumatic Stress, 15, 2002, pp. 407-413.

Gul, Showkeen Bilal Ahmad. "Assessment and Understanding of Gujjar and Bakerwal Women's Health in Jammu and Kashmir". Journal of Business Management \& Social Sciences Research, Vol. 3 No. 3, March 2014, pp. 37-43.

Johnson, Michael P. "Patriarchal Terrorism and Common Couple Violence: Two Forms of Violence against Women". Journal of Marriage and the Family, Vol. 57, No. 2 (May, 1995), pp. 283-294;

Khan, Fawad and Danish Mustafa. "Navigating the Contours of the Pakistani Hazardscapes: Disaster Experience versus Policy". Chapter 8, May, 2007, Available on website: https://thebookee.net/fa/fawadkhan, accessed on November 2017;

Lundberg, Shelly J and Robert A Pollak. "Noncooperative Bargaining Models of Marriage". American Economic Review Papers and Proceedings. Vol. 84 No. 2, 1994. Pp. 132-137;

Malamuth, Neil M., and James V.P. Check. "The Effects of Mass Media Exposure on Acceptance of Violance against Women: A Field Experiment". Journal of Research in Personality 15, 1981, pp. 436-446;
Millennium Project. 2005. Investing in Development: A Practical Plan to Achieve the Millennium Development Goals, Overview. London: Earth scan;

Ministry of Planning, Development and Reform. 2013. Pakistan Millennium Development Goals Report. Pakistan: Ministry of Planning, Development and Reform;

P. Sen. "Enchancing Women's Choices in Responding to Domestic Violence in Calcutta: A Comparison of Employment and Education". The European Journal of Development Research, Vol. 11 No. 2, December 1999, pp. 65-86;

Planned project activities 2002-2003 addendum, International fund for Agricultural Development, Executive Board-Seventy-Seventh Session, Rome, 10-11 December, 2002;

S.R. Schuler., Hashemi S.M., Riley A.P. and Akhter S. "Credit Programs, Patriarchy and Men's Violence against Women in Rural Bangladesh". Soc.Sci Medicine, Vol. 43 No. 12, 1996, pp. 1729-1742;

Sood, Sarita and Arti Bakshi, "Quality of life: Gender differences in aged Kasmiri migrants in Jammu, India", AP Journal Psychological Medicine, Vol. 15 (2) July-Dec 2014, pp. 187-192;

Sudan, Falendra K. "Livelihood Diversification and Women Empowerment Through SelfHelp Micro Credit Programme: Evidence from Jammu and Kashmir". Indus Journal of Management \& Social Sciences, Vol. 1 No. 1, Fall 2007, pp. 90-106;

United Nations Security Council Resolution. 1325. 2000.

United Nations Commission on Human Rights. April 2003.Agenda item 10, Economic, Social and Cultural rights. Geneva: United Nations Commission on Human Rights;

United Nations Report on Indicators for Promoting and Monitoring the Implementation of Human Rights. Realizing the Future We Want for All: Report to the Secretary-General. UN System Task Team Report on the Post-2015 Development Agenda, June 6, 2008. Available on: www2. ohchr.org/english/bodies/icm-mc/docs/ HRI.MC.2008.3EN.pdf. accessed on December, 2017;

Vandemoortele, Jan. "MDGs: Misunderstood Targets?. International Poverty Centre. No. 28, January, 2007. 